\title{
The Interference Of Some Sasaknese Consonants Into English Consonants In 2019/2020
}

\author{
Masyudi \\ English Department, Faculty of Education for Language and Arts \\ Mataram Insitute of Teacher Training and Education \\ E-mail: amaqmasyudi@gmail.com
}

\begin{abstract}
This research aimed to investigate the interference of some Sasaknese consonants into English consonants in 2019/2020 by using descriptive qualitative research design. The object of this research was the pronunciation of Sasaknese native speakers in speaking English, especially that for $/ \mathrm{J} /,[1], / \theta /, / \delta /$, and /3/. The informants of this research were 11 native speakers of Sasaknese who were able to speak English. In order to obtain the data, some of them were recorded while having dialogue with the researcher, and some others were recorded while they were performing a speech in front of their friends. The result showed that there were 182 occurrences of the investigated sounds, in which 106 were interfered by the respondents, meaning that 76 others were pronounced accurately. 12 sounds occurred in pronouncing /fl and 8 were interfered with /s/, 77 occurred in pronouncing [.] and 27 were interfered with [R], 66 occurred in pronouncing / $/ /$ and 49 were interfered with $/ d /$, 6 occurred in pronouncing /3/ and 3 were interfered with /J/, 3 others were interfered with /z/, and 21 occurred in pronouncing $/ \theta /$ with all of these sounds interfered into $/ \mathrm{t} /$. The interference occurred due to the absence of these sounds in standard Sasaknese consonant system and their difficulty to pronounce by Sasaknese native speakers. In addition, another cause was also the lack of respondents' knowledge about the investigated sounds. Meanwhile, some consonants pronounced correctly proved that some respondents were aware of the particular consonants, although they fell back into Sasaknese phonological system when they lost their concentration.
\end{abstract}

Keywords: interference, pronunciation, consonan

In discussing about language, Brown (2000: 5) states that language is a system of arbitrary conventionalized vocal, written, or gestural symbols that enable members of a given community to communicate intelligibly with one another. This statement explains that language not only appears in one form. In fact, it is an arbitrary system of vocal (oral), textual (written), and gestural symbols for the language users to use in communication.

In oral communication, language sounds always take an important role. The study of language sounds is called phonology, as what McMahon (2002: 2) states, that phonology is the language-specific selection and organization of sounds to signal meanings. This claims that the meaning of the language is also signalled with sounds organization, not merely in written from. Therefore, phonology does play an important role in human's oral communication.
In this research, the researcher aims to investigate the phonological field of linguistics. There has been found some bias in how the foreign language users at the researcher's village use English as a foreign language, especially in pronouncing some particular sounds of English consonants. Kecskes and Papp (2000: 20) state "To the extent that instruction in a certain language is effective in promoting proficiency in that language, transfer of thisproficiency to another language will occur." This statement deals with the discussion of mother tongue effect towards foreign language learning, in which the mastery of mother tongue language (L1) strongly affects the proficiency to another language, in this case Foreign Language (FL).

The role of the native language influences in the target language has been a controversial topic. Most researchers agree 
that the learner's native language influences the pronunciation of the target language. It is significant to compare the structure of one's native language with the structure of the target language, which is known as Contrastive Analysis. Contrastive Analysis believes that the similarities of the two languages will facilitate learning whereas the differences will increase the learners' difficulty to learn. Hence, the influence of native language in the learners' target language can be positive and negative.

\section{Review of Related Literature}

This chapter discusses about the review of related literature. This section reviews the related theory for the field in this research. This chapter begins with general terminologies of phonology and phonetics. It further continued with more specific discussions about manners and places of articulations. In order to make it more targeted to this research, the discussion is continued to consonants, the feature of Sasaknese and English consonants along with their difference, and finally it is continued with the review of the previous study in order to have a comparison between this particular research and the previous researches.

\section{Phonology}

In discussing about phonology, McMahon (2002: 2) states that phonology is the language-specific selection and organisation of sounds to signal meanings. It means that the meanings of the language are also strongly affected by phonology with its knowledge of organization of sounds. Meanwhile, in the same discussion, Burleigh and Skandera (2005: 5) states that phonology deals with the speakers' knowledge of the sound system of a language. He further states that it exclusively concerned with langue or competence. Looking at some explanations about phonology above, the researcher concludes that phonology is the study of sound system in English dealing with competence to signal meanings with organizations of sound.

Bringing the reader to deeper discussion about phonology, Burleigh and
Skandera divides phonology into two subparts, namely: segmental phonology and suprasegmental phonology.

Segmental Ponology

According to Burleigh and Skandera (2005: 5), segmental phonology is based on the segmentation of language into individual speech sounds provided by phonetics. They further state that unlike phonetics, segmental phonology is not interested in the production, the physical properties, or the perception of these sounds, but in the function and possible combinations of sounds within the sound system. In the same discussion, Nordquist (2016: 1) states that segmental phonology is any one of the discrete units that occur in a sequence of sounds. Thus, segmental phonology is phonology that deals with the individual division of sounds focusing on its functions and combinations occurring in a sequence of sounds.

\section{Supra-segmental Phonology}

Supra-segmental phonology, also called prosody, is concerned with those features of pronunciation that cannot be segmented because they extend over more than one segment, or sound (Burleigh and Skandera, 2005: 5). Nordquist (2015: 1), in the same discussion, says that suprasegmental phonology refers to a phonological property of more than one sound segment. Such features include stress, rhythm, and intonation also called pitch contour or pitch movement. Thus, supra-segmental phonology is the phonology which deals with phonological feature of more than one segment and cannot be divided, including stress, rhythm, and intonation.

Looking at these two parts of phonology, one which correlates to the analysis of this research is segmental phonology. This is due to the focus of this research relying on the individual speech sound productions, especially English speech sound productions which are interfered by Sasaknese.

\section{Phonetics}

In Burleigh and Skandera's view (2005: 3 ), phonetics is concerned with the performance which divides concrete utterance into individual speech sounds. It means that 
phonetics roles to cut the utterance into pieces of sounds. Meanwhile, McMahon (2002: 1) states that phonetics provides objective ways of describing and analysing the range of sounds humans use in their languages. He further states that phonetics has strong association with anatomy, physics and neurology.

In Norquist's explanation (2016: 1), in more discussion about phonetics, he says that phonetics is the branch of linguistics that deals with the sounds of speech and their production, combination, description, and representation by written symbols. From these definitions, the researcher concludes that phonetics is the branch of linguistics dealing with the written symbol describing the speech sound and their production, combination, description, and representation which is associated with anatomy, physics, and neurology. The discussion about phonetics in this research is strongly needed in order to be able to describe the speech sound in the written form.

\section{Articulatory Phonetics}

Articulatory phonetics identifies precisely which speechorgans and muscles are involved in producing the different sounds of theworld's languages (McMahon, 2002: 1). It is divided into places and manners of articulation.

\section{Places of Articulation}

Before going to the places of articulation, it is worthy to review the speech organs human has. The following figure shows the human's speech organs according to Odden (2005: 12):

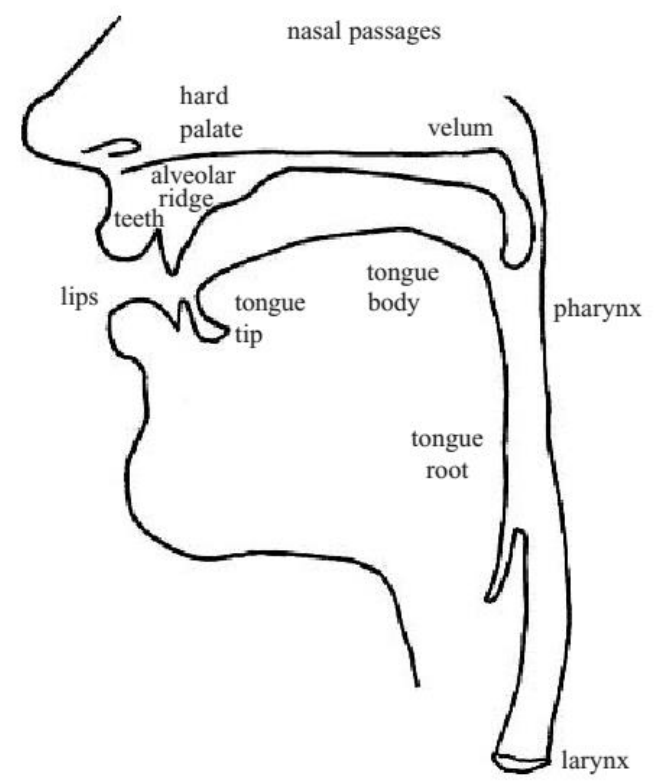

Figure 2.1: Human Speech Organs (Odden, 2005: 12)

The figure above illustrates the anatomical landmarks which are important for speech production research, including this particular research. Odden (2005: 12) in this case states that since sound production needs airflow, it generally begins with the lungs driving out air through the mouth. This process then continues with whether there is an addition of voice, producing voiced sound or without voice, producing voiceless sound. The speech organs illustrated above is the basic foundation of introducing the places of articulation.

McMahon (2002: 30) states that place of articulation is the location of active and passive articulators. In English, as he illustrates, there are eight places of articulation. Meanwhile, according to Burleigh and Skandera (2015: 21), there are thirteen possible places of articulation in the languages of the world. These are some places of articulation which are limited to this research.

\section{Bilabial}

McMahon (2002: 31) states that for a bilabial sound, the active articulator is the bottom lip, and the passive articulator is the top lip. /p/ in pie is voiceless bilabial plosive $/ \mathrm{b} /$ in by is voiced bilabial plosive $/ \mathrm{m} /$ in $m y$ is 
voiced bilabial nasal. Therefore, bilabial sounds are produced with both lips.

There is at least one further English phoneme which to an extent fits under bilabial discussion: this is the approximant $/ \mathrm{w} /$ in wet. In producing $/ \mathrm{w} /$, the lips are certainly approximated, though not enough to cause friction or obstruct the airflow; but one should be able to feel that the back of the tongue is also bunched up. This additional articulation takes place at the velum, so that $/ \mathrm{w} /$ is not simply a labial sound, but a labial-velar one. The example of bilabial in Sasaknese is maeh $/ \mathrm{mach} /$ which is 'give me' in English.

\section{Labio-Dental}

For labio-dental sounds, the active articulator is the bottom lip, butit moves up to the top front teeth (McMahon, 2002: 31). /f/ in fat is voiceless labio-dental fricative. / $/$ / in vat is voiced labio-dental fricative teeth. There is no labio-dental in Sasaknese. Therefore, in Sasaknese, /v/ and /f/ often turn into $/ \mathrm{p} /$.

\section{Dental}

In most English sounds, and most speech sounds in general, the active articulator is part of the tongue; to avoid confusion, places of articulation where the tongue is involved are therefore generally called afterthe passive articulator (McMahon, 2002: 31). In his discussion, McMahon further states that for the two dental fricatives, it follows that thepassive articulator is the top front teeth; the active articulator isthe tipof the tongue. The tongue itself is conventionally divided into thetip (the very front); the blade (just behind the blade, and lying oppositethe alveolar ridge); the front (just behind the blade, and lying oppositethe hard palate); the back (behind the front, and lying opposite thevelum); and the root (right at the base, lying opposite the wall of thepharynx)./ $/ \theta /$ in thigh is voiceless dental fricative, while /ठ/ inthyisvoiced dental fricative. For clearer understanding, the figure for dental is shown below:

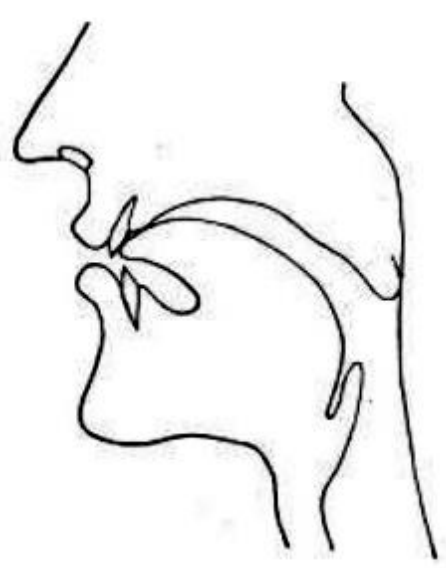

Figure 2.2: Dental

It can be seen in the picture above that in producing dental sounds, the tongue is placed between lower and upper teeth. There is no dental in Sasaknese since the speakers of Sasaknese never apply such kind of tongue placement. Even in producing $/ \theta /$ and $/ \delta /$, these sounds often become alveolar, which are respectively /d/ and /t/.

\section{Alveolar}

Alveolar sounds are produced by the tip or blade of the tongue movingup towards the alveolar ridge, the bony protrusion that can be felt if tongue is curledback just behind the top front teeth (McMahon, 2002: 32).The examples of alveolar are shown in the following table:

\begin{tabular}{|c|c|c|c|}
\hline $\begin{array}{c}\text { No } \\
\cdot\end{array}$ & $\begin{array}{c}\text { Sound } \\
\text { Symbol } \\
\mathbf{S}\end{array}$ & $\begin{array}{c}\text { Description } \\
\mathbf{S}\end{array}$ & $\begin{array}{c}\text { Sampl } \\
\mathbf{e} \\
\text { Words }\end{array}$ \\
\hline $\mathbf{1 .}$ & $/ \mathbf{t} /$ & $\begin{array}{c}\text { voiceless } \\
\text { alveolar } \\
\text { plosive }\end{array}$ & Tie \\
\hline $\mathbf{2 .}$ & $/ \mathbf{d} /$ & $\begin{array}{c}\text { voiced } \\
\text { alveolar } \\
\text { plosive }\end{array}$ & Die \\
\hline $\mathbf{3 .}$ & $/ \mathbf{n} /$ & $\begin{array}{c}\text { voiced } \\
\text { alveolar } \\
\text { nasal }\end{array}$ & Nigh \\
\hline $\mathbf{4 .}$ & $/ \mathbf{s} /$ & $\begin{array}{c}\text { voiceless } \\
\text { alveolar } \\
\text { fricative }\end{array}$ & Sip \\
\hline $\mathbf{5 .}$ & $/ \mathbf{z} /$ & $\begin{array}{c}\text { voiced } \\
\text { alveolar } \\
\text { fricative }\end{array}$ & Zip \\
\hline $\mathbf{6 .}$ & {$[\mathbf{x}]$} & voiced & Rip \\
\hline
\end{tabular}




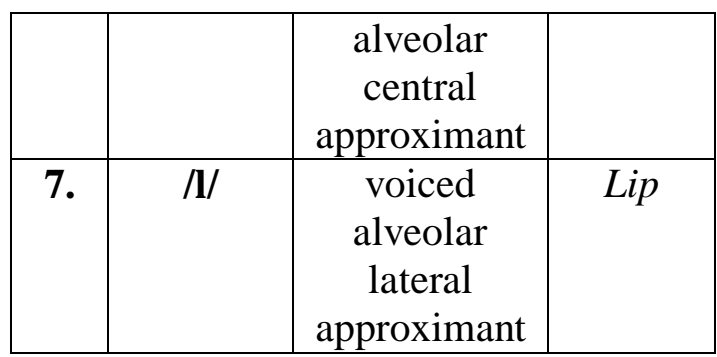

Table 2.1: Alveolar Sounds

In order to make it clear, the following figure illustrates where alveolar is located in the speech organ:

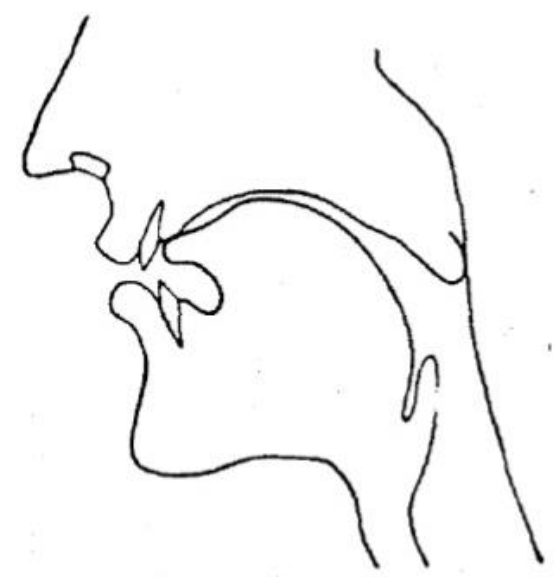

Figure 2.3: Alveolar

Alveolar is available in standard Sasaknese. The example of alveolar in Sasaknese is tie /tiə/, and benang /bənay/, which means 'there it is' and 'thread' respectively. However, /z/ is not available in standard Sasaknese phoneme, although Sasak people can easily mention it due to the high frequency of utterances of other languages containing /z/ used by Sasaknese. This phenomenon means that there will be no problem for Sasaknese to produce any sound patterns in English - the sound pattern containing sound $/ \mathrm{z} /$.

\section{Research Design}

Research method is necessary for researchers because it can guide the researchers to achieve their focuses of the study based on the problems arising in the study (Sudaryanto, 2015: 25). In conducting this research, the researcher used a qualitative research design. Creswell (2014: 69) states that qualitative research tries to understand and interpret human and social behavior participants in a particular social setting. This approach involves asking participants broad, general questions, collecting the views of participants, and analyzing the collected information for exploring and understanding a central phenomenon.

This study was descriptive qualitative research. It is called descriptive because this research attempted to describe all aspects of phonetics of English used by Sasaknese as the result of the interference of their L1 acquisition. Ary et al. (2009: 23) states that the result of qualitative research design is a narrative report, that the social reality experienced by the participants could be understood. Thus, after conducting this research the conclusion was arranged in narrative in order to let the readers know the process done in this research previously.

\subsection{Research Location}

The Sasak language is spoken on the island of Lombok by around 2.7 million speakers or $85 \%$ of the population of Lombok, which was recorded as 3,169,050 (Austin, 2012: 231). The research location was at any possible place around Lombok where the native speakers of Sasaknese are found to be recorded. This was due to the fact that no matter where the respondents were from, as long as they were the native speakers of Sasaknese, the language they used always had identical characteristics, although the language accent used is different.

\subsection{Data Source}

It has been discussed at the previous chapter that Sasak shows complex system of speech levels, including varieties of dialects. For this research, the data from the native speakers of Sasaknese were obtained. Before engaging in the collection of any data, the participants were not informed about the purpose of the study in order to get natural result. In addition, demographic information such as age, gender, and educational background, as well as information about their prior English-language learning experience were collected from the participants. Demographic information was used to examine whether there was any correlation between participants' articulation pattern and their experience with Englishlanguage learning. Here are the characteristics of the respondents investigated in this research: 
- The respondents were native speakers of Sasaknese.

- They were able to speak in English.

- They were between 14 up to 70 years old.

- They were healthy and had good articulation, or not defective in speech production (their organs of speech were normal).

- They were available as informants.

In this case, 11 people were recorded for collecting the data. These 11 people were the native speakers of Sasaknese. Here are the data of all the informants in this research. The demographic information about the informants was obtained by collecting the answers of the questionnaires provided for the informants:

\begin{tabular}{|c|c|c|c|c|c|c|}
\hline No. & Name & Gender & $\begin{array}{l}\text { Age } \\
\text { (years old) }\end{array}$ & Last Study & $\begin{array}{l}\text { Professi } \\
\text { on }\end{array}$ & Address \\
\hline 1. & $\mathrm{RH}$ & Male & 20 & $\begin{array}{l}\text { Senior High } \\
\text { School }\end{array}$ & $\begin{array}{l}\text { Undergg } \\
\text { aduate } \\
\text { student }\end{array}$ & $\begin{array}{l}\text { Jurang Ripin, Batukliang, } \\
\text { Central Lombok }\end{array}$ \\
\hline 2 & $\mathrm{KR}$ & Male & 25 & $\begin{array}{l}\text { Senior High } \\
\text { School }\end{array}$ & Waiter & Sade, Bodak, Central Lombok \\
\hline B. & SM & Male & 14 & $\begin{array}{l}\text { Elementary } \\
\text { School }\end{array}$ & Student & Selong, East Lombok \\
\hline 4. & NW & Male & 16 & $\begin{array}{l}\text { Junior High } \\
\text { School }\end{array}$ & Student & Selong, East Lombok \\
\hline 5. & WR & Female & 16 & $\begin{array}{l}\text { Junior High } \\
\text { School }\end{array}$ & Student & Penujalk, Central Lombok \\
\hline 6. & EY & Female & 14 & $\begin{array}{l}\text { Elementary } \\
\text { School }\end{array}$ & Student & $\begin{array}{lll}\text { Lendang } & \text { Randu, } & \text { Central } \\
\text { Lombok } & & \end{array}$ \\
\hline 7. & SF & Female & 16 & $\begin{array}{l}\text { Junior High } \\
\text { School }\end{array}$ & Student & Kebun Randu, Central Lombok \\
\hline 8. & $\mathrm{WH}$ & Male & 23 & S1 & $\begin{array}{l}\text { Graduat } \\
\text { S } \\
\text { Student }\end{array}$ & Penujak, Central Lombok \\
\hline 9. & AP & Male & 16 & $\begin{array}{l}\text { Junior High } \\
\text { School }\end{array}$ & Student & Kebun Nyiur, Central Lombok \\
\hline 10. & ws & Male & 16 & $\begin{array}{l}\text { Junior High } \\
\text { School }\end{array}$ & Student & Barabali. Central Lombok \\
\hline 11. & $\mathrm{HG}$ & Male & 16 & $\begin{array}{l}\text { Junior High } \\
\text { School }\end{array}$ & Student & Pemenang, North lombols \\
\hline
\end{tabular}

\section{Findings and Discussion}

This chapter discusses the results of the analysis along with its scientific causes. It is based on the research done with the research method provided in the previous chapter. The first problem of this research stating "What Sasaknese consonants interfere into English consonants?" was answered with the findings of this research. Furthermore, the second problem of this research stating "How do Sasaknese consonants interfere into English consonants during the production?" was answered with the theories of interference by Sudipa et al. (2011). These findings and discussion are the basic foundation for the research to be concluded.

\section{Findings}

This section explains the data obtained after conducting the research. In this section, the interferences of some Sasaknese consonant sounds productions into English are provided based on the data obtained. These findings, therefore, answer the first statements of the problem stated in the previous chapter. Before going further, the process of recording is illustrated.

\section{The Recording Process}

Before recording the participants, the condition was first observed. This observation aimed to see whether the informants were suitable to the characteristics of the participants required in this research. In this case, some of the respondents have been well known by the researcher. For these respondents, the information obtaining process was not really required.

Meanwhile, those informants who are unknown by the researcher were first investigated to obtain their basic information, whether they met the requirements or not. This investigation was done by asking the informants' family or friends.

\section{Interference Occurrences}

As what has been explained in the previous chapter that this study was limited to some Sasaknese consonants, which interfered into English consonants productions. Those sounds were $/ \int /,[\mathrm{s}], / \delta /, / \zeta /$ and $/ \theta /$. The results below are those which have been classified accordingly - after reducing the irrelevant data and selecting the required data for this research. These data were taken by recording the informants.

Based on the result of the analysis, after analyzing the collected data, there were 182 occurrence of all the sounds investigated in this research; 12 for $/ \int /, 77$ for $[\mathrm{I}], 66$ for $/ ð /, 6$ for $/ 3 /$, and 21 for $/ \theta /$. The following chart shows the percentage of the occurrence.

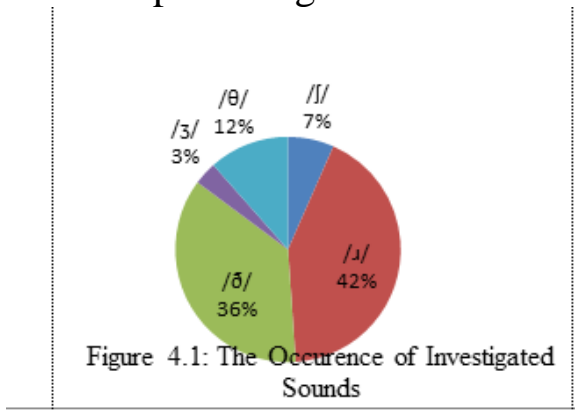

The chart above shows that the sound [I] occurred the most frequently with $42 \%$ of the percentage, and the sound / $3 /$ hardly 
occurred with only $3 \%$ of the occurrence. Under $[\mathrm{I}]$, there is the sound / $/ /$ with $36 \%$ of the percentage, followed by $/ \theta /$ with $12 \%$ of the occurrence, and then $/ \delta /$ with $7 \%$ of the occurrence, and the last is $/ 3 /$ with $3 \%$ of the percentage.

Furthermore, from these 182 occurrences, 106 were interfered by Sasaknese, meaning that 76 others were pronounced accurately. In detail, from all these 182 occurrence, 12 sounds occurred in pronouncing $/ \mathrm{S} /$ and 8 were interfered, 77 occurred in pronouncing $[\mathrm{I}]$ and 27 were interfered, 66 occurred in pronouncing / // and 49 were interfered, 6 occurred in pronouncing $13 /$ and all were interfered, and 21 occurred in pronouncing $/ \theta /$ with all of these sounds interfered. The following table shows the percentages of the interferences found for each sound.

\begin{tabular}{|l|l|c|c|}
\hline No. & Sounds & $\begin{array}{c}\text { Percentages } \\
\text { of } \\
\text { Interferences }\end{array}$ & $\begin{array}{c}\text { No } \\
\text { Interference }\end{array}$ \\
\hline 1. & $/ \mathrm{J} /$ & $66.67 \%$ & $33 \%$ \\
\hline 2. & {$[\mathrm{I}]$} & $35.06 \%$ & $65 \%$ \\
\hline 3. & $/ \mathrm{d} /$ & $74 \%$ & $26 \%$ \\
\hline 4. & $/ 3 /$ & $100 \%$ & $0 \%$ \\
\hline 5. & $/ \theta /$ & $100 \%$ & $0 \%$ \\
\hline
\end{tabular}

Table 4.1: The Percentage of the Interferences of Each Sound

The table above shows that not all occurrences of the sounds were interfered by Sasaknese. In pronouncing / $/$, Sasaknese interfered $66.67 \%$ of the sounds, and the rest $33 \%$ were not. Here, the percentage of the interference was higher than that which was not interfered. In pronouncing [x], Sasaknese interfered $35.06 \%$ of these sounds and the rest $65 \%$ were not interfered. It means that most of $[\mathrm{I}]$ sounds were not interfered by Sasaknese. In pronouncing /ð/, 74\% were interfered and $26 \%$ were not. Meanwhile, in pronouncing $/ 3 /$, and $/ \theta /$, all sounds were interfered. In other words, the respondents never pronounced these sounds correctly. This result therefore answered the first statement of the problem stated in the previous chapter.
Discussion

Based on the result of the analysis, Sasaknese brought out the interferences in pronouncing some consonant sounds, namely / $/$, [ı], /ð/, /Z/, and / $/$ / sounds. All respondents had been recorded and analyzed for this reserach. Despite the different dialects of the six respondents, the language systems they had were still identical, in other words, they have the same vowels, diphthongs, and consonants, united with the 18 initial consonants of the system called Carakan, and 1 single consonant, glottal stop.

There were two problems to be answered in this research. The first problem has been answered in the previous section of this chapter by identifying some consonants interferences performed by Sasaknese. Based on the result of the analysis, there were 8 interferences of $/ \mathrm{J} /$ sounds of all the 12 occurrences, 27 interferences of $[\mathrm{I}]$ sounds of all the 50 occurrences, 44 interferences of $/ ð /$ sounds of all 66 occurrences, 6 interferences of $/ 3 /$ sounds of all 6 occurrences, and 21 interferences of $/ \theta /$ sounds of all the 21 occurrences. The total number of the interference was 106 of all the 182 occurrences.

\section{Conclusion and Suggestions}

The results of this study indicated that English pronunciation is troublesome for the participants. It was proven by percentage of those who produced pronunciation interference. For those reasons, a serious attention must be given since the participants were supposed to be a good model of English pronunciation for their students. The fact that studies on this field is relatively few has become another reason for further studies from a wide variety of perspectives and approaches conducted in the future.

\section{Conclusion}

This study addressed three research questions. The first question was about identifying some consonant interference occurring in pronouncing English consonants by the native speakers of Sasaknese. The second question investigated efforts to analyze how these interferences occurred. For the first research question, this study revealed 
that pronunciation interferences consisted of segmental interferences in consonant sounds production.

The result of this research showed that the interference occurred in pronouncing $/ \theta /$, $/ ð /, / \delta /, / \zeta /$, and $[x]$, however some sounds of IS/ and [I] remained correct due to its familiarity for Sasaknese native speakers. Therefore, not all of these sounds were interfered by standard consonant systems of Sasaknese.

\section{Suggestions}

Since the participants in this study are the model for their students, it is a must for them to be aware of their shortages on English pronunciation. Their responsibility to give the very basic of English, which is English sounds, has to be the main concern and becomes very crucial because they teach English sounds in the students' golden age. This means during this age the students are much easier to adapt and adopt English sounds from their teachers. Several suggestions based on the findings of this study are given.

1. First, because the interferences were drawn by contrastive analysis, giving comparison and contrast of both English and Bahasa Indonesia seems appropriate to be applied. As revealed in the findings, one of the causes of the interferences was their insufficient knowledge.

2. For adult learners, they should increase the curiosity to find out the correct pronunciation for every words they have or are going to add. This will contribute to their awareness of the differences between Sasaknese language systems from English language systems.

3. Another suggestion to give is that the effort of improving their pronunciation should not be only self-driven. Support from the institution or foundation is inevitable. The support can be by giving them teacher professional development program. This is very crucial to notice since the teachers are the frontliners and have a very big influence and responsibility in their students' English pronunciation. Since pronunciation is a form of behavior, consequently, continuous pronunciation trainings should be given.

\section{References}

Ary, Donald., Jacobs, Lucy Cheser, Razavieh, Asghar, Sorensen, Chris. (2009). Introduction to Research ( $8^{\text {th }} \mathrm{Ed}$.). Belmont: Wadsworth Publishing.

Brown, H. D. (2000). Principles of Language Learning and Teaching ( $4^{\text {th }} E d$.). San Francisco: Longman Inc.

Burleigh, P. and Skandera P. (2005). Manuals of English Phonetics and Phonology. Germany: CompArt.

Creswell, John W. (2014). Research Design: Qualitative, Quantitatve, and Mixed Methods Approached, Fourth Edition. Los Angeles: Sage Publications, Inc.

Kecskes, Istvan and Papp, Tunde. (2000). Foreign Language and Mother Tongue. New York: Lawrence Erlbaum Associates, Inc.

Odden, D. (2005). Introducing Phonology. New York: Cambridge University Press.

McMahon, April. (2002). An Introduction to English Phonology. Edinburgh: Edinburgh University Press

Nordquist, R. (2015). "Suprasegmental (Speech)". Retreived from http://grammar.about.com on January $14^{\text {th }} 2017$.

(2016). "Segment (Phonology and Phonetics)". Retreived from http://grammar.about.com on January $14^{\text {th }} 2017$.

(2016). "Glossary of Grammatical and Rhetorical Terms". Retreived from http://grammar.about.com on January $14^{\text {th }} 2017$.

Sudaryanto. (2015). Metode dan Aneka Teknik Analisis Bahasa. Yogyakarta: Duta Wacana University Press.

Sudipa, I. N, Rajeg, I. M., and Laksmini, L. P. (2011) Interferensi: Pengaruh Bahasa Indonesia dalam Bahasa Inggris. Udayana: Udayana University Press. 